\title{
Increasing Amounts of Conjugated Linoleic Acid (CLA) Progressively Reduces Milk Fat Synthesis Immediately Postpartum*
}

\author{
C. E. Moore, ${ }^{1}$ H. C. Hafliger, III, ${ }^{1}$ O. B. Mendivil, ${ }^{1}$ S. R. Sanders, ${ }^{1}$ \\ D. E. Bauman, ${ }^{2}$ and L. H. Baumgard ${ }^{1}$ \\ ${ }^{1}$ Department of Animal Sciences, \\ The University of Arizona, Tucson 85721 \\ ${ }^{2}$ Department of Animal Science, \\ Cornell University, Ithaca, NY 14853
}

\begin{abstract}
Mixed conjugated linoleic acid (CLA) isomers decrease milk fat synthesis during established lactation, but their ability to cause milk fat depression (MFD) immediately postpartum remains unclear. Multiparous Holstein cows $(n=19)$ were randomly assigned to 1 of 4 doses of rumen-protected (RP) CLA supplements (0, 200,400 , and $600 \mathrm{~g} / \mathrm{d}$ ); each dose provided equal amounts of fatty acids by replacing and balancing treatments with an RP supplement of palm fatty acid distallate. Doses provided a total of $468 \mathrm{~g}$ fatty acids/d and $0,62,125$, or $187 \mathrm{~g}$ of mixed CLA isomers/d, respectively. The CLA supplement contained a variety of CLA isomers: $5.4 \%$ trans- 8 , cis- $10 ; 6.3 \%$ cis- 9 , trans- $11 ; 7.9 \%$ trans-10, cis-12; and 8.2\% cis-11, trans-13 CLA. Each group received treatments from approximately -10 to $21 \mathrm{~d}$ relative to calving. To improve palatability and ensure complete consumption, doses were mixed with equal amounts of steam-flaked corn and dried molasses; one-half the supplement was fed at $0600 \mathrm{~h}$, and the remaining supplement was fed at $1800 \mathrm{~h}$. Milk yield and individual feed intake were recorded daily, and milk samples were obtained from each cow every 2 nd day (at both milkings) starting on d 1 postpartum. There were no differences in dry matter intake (17.1 $\mathrm{kg} / \mathrm{d})$, milk yield $(34.2 \mathrm{~kg} / \mathrm{d})$, protein content $(3.74 \%)$, lactose content $(4.61 \%)$, or yield of milk protein or lactose. The CLA supplementation decreased overall milk fat content in a dose-responsive manner (4.57, 3.97, 3.32 , and 3.10, respectively), and milk fat yield displayed the same progressive decline. The dose-dependent decrease in milk fat content was evident during wk 1 and became highly significant during wk 2 and 3 . The milk fat yield response pattern was similar, and
\end{abstract}

\footnotetext{
Received September 17, 2003.

Accepted January 28, 2004.

Corresponding author: Lance H. Baumgard; e-mail: baumgard@ ag.arizona.edu.

*This work partially supported by the University of Arizona Experiment Station \#ARZT-136339-H-24-130.
}

by $\mathrm{d} 21$, the highest RP-CLA supplement decreased milk fat content and yield by 49 and $56 \%$, respectively. These data clearly indicate RP-CLA can markedly (40 to $50 \%$ ) induce MFD immediately postpartum without negatively affecting other production parameters.

(Key words: conjugated linoleic acid, milk fat, transition period, dairy cow)

Abbreviation key: CLA = conjugated linoleic acid, EBAL = energy balance, MFD = milk fat depression, NEBAL = negative EBAL, $\mathbf{R P}=$ rumen-protected .

\section{INTRODUCTION}

Studies attempting to increase the content of conjugated linoleic acid (CLA) in milk fat from lactating dairy cows serendipitously demonstrated that CLA administration dramatically decreased milk fat yield and content (Loor and Herbein, 1998; Chouinard et al., 1999a). Subsequent short-term studies confirmed that abomasally infusing supplemental CLA caused milk fat depression (MFD; Chouinard et al., 1999b; Kraft et al., 2000; Mackle et al., 2003) and identified trans-10, cis12 as a responsible CLA isomer (Baumgard et al., 2000). Long-term experiments utilizing rumen-protected (RP) CLA supplements $\left(\mathrm{Ca}^{++}\right.$salts $)$indicate CLA also decreases milk fat when fed to cows consuming a TMR or those rotationally grazed (Medeiros et al., 2000; Giesy et al., 2002; Perfield et al., 2002). In addition, dietary CLA has been reported to decrease milk fat synthesis in lactating pigs (Harrell et al., 2000; Poulos et al., 2000) and nursing women (Masters et al., 2002).

The aforementioned cattle studies have utilized cows in mid to late lactation. Studies conducted in early lactation indicate that RP-CLA fed at levels effective in established lactation (i.e., 12.5 to $100 \mathrm{~g} / \mathrm{d}$; Giesy et al., 1999; Bernal-Santos et al., 2003) are ineffective at reducing milk fat synthesis during the first few weeks postpartum. Therefore, it appears that the mammary gland is either insensitive or less sensitive to CLA immediately postpartum (1 to $21 \mathrm{DIM}$ ). We hypothesized 
that milk fat synthesis could be reduced immediately postpartum, but would require a much larger CLA dose.

The periods immediately prior to and following calving are associated with extensive metabolic adaptations. Characteristically, cows in this transition phase are secreting more energy than they consume (Drackley, 1999). As a consequence, animals experience a substantial negative energy balance (NEBAL), which is associated with an increased risk of metabolic disorders and health problems (Goff and Horst, 1997; Drackley, 1999) as well as reduced reproductive performance (Lucy et al., 1992; Beam and Butler, 1999). For decades the primary management method utilized to alleviate the magnitude of NEBAL was feeding additional energy in the form of either increased concentrates or fats (Schingoethe and Casper, 1991; Grummer et al., 1995). Unfortunately, the incidence and severity of NEBAL continues to be the primary issue surrounding transition period failures (Beam and Butler, 1999; Drackley, 1999).

An alternative approach to improving NEBAL is to reduce milk energy secretion. Reducing the nutrient demand of milk synthesis via initiating MFD should alleviate the magnitude of NEBAL and also reduce DIM to energy balance (EBAL) nadir. Alleviating the severity of NEBAL immediately after parturition may allow for increased production, decreased incidence of metabolic disorders (e.g., ketosis, fatty liver, etc.), and improved reproduction. The objective of this study was to determine the quantity of a dietary RP-CLA supplement required to achieve extensive MFD during lactogenesis and the early phase of galactopoiesis, thus alleviating or reducing the severity of NEBAL during the transition period.

\section{MATERIALS AND METHODS}

\section{Design, Animals, and Treatments}

The University of Arizona Institutional Animal Care and Use Committee approved all procedures involving animals. Multiparous Holstein cows $(\mathrm{n}=19)$ were blocked by predicted calving date and randomly assigned to 1 of 4 RP-CLA supplement doses (0, 200, 400, and $600 \mathrm{~g} / \mathrm{d}$; Bioproducts Inc., Fairlawn, $\mathrm{OH}$ ) with each dose providing equal amounts of total fatty acids by replacing and balancing treatments with EnerGII ${ }^{\circledR}$ (a RP supplement of palm fatty acid distilla; Bioproducts Inc.). Doses provided a total of $468 \mathrm{~g}$ fatty acids/d and $0,62,125$, or $187 \mathrm{~g} \mathrm{CLA} / \mathrm{d}$, respectively. The CLA supplement contained a variety of CLA isomers $(5.4 \%$ trans- 8 , cis- $10 ; 6.3 \%$ cis- 9 , trans- $11 ; 7.9 \%$ trans- 10 , cis12; and $8.2 \%$ cis-11, trans-13 CLA; Table 1). Each group received treatments from approximately -10 to $21 \mathrm{~d}$ relative to calving. To improve palatability and ensure
Table 1. Fatty acid composition of lipid supplements. ${ }^{1}$

\begin{tabular}{|c|c|c|}
\hline Fatty acid & Control & CLA $^{2}$ \\
\hline & \multicolumn{2}{|c|}{$-(\%$ of fatty acids $)$} \\
\hline $12: 0$ & 0.24 & 0.15 \\
\hline 14:0 & 1.13 & 0.37 \\
\hline $15: 0$ & 0.06 & 0.02 \\
\hline $16: 0$ & 47.61 & 15.38 \\
\hline $16: 1$ cis -9 & 0.16 & 0.14 \\
\hline $18: 0$ & 4.48 & 2.24 \\
\hline $18: 1$ cis -9 & 35.53 & 34.87 \\
\hline $18: 2$ cis -9, cis -12 & 7.66 & 3.81 \\
\hline 18:2 trans -8, cis -10 CLA & $<0.01$ & 5.38 \\
\hline 18:2 cis-9, trans-11 CLA & $<0.01$ & 6.34 \\
\hline $18: 2$ trans -10, cis-12 CLA & $<0.01$ & 7.88 \\
\hline 18:2 cis -11 , trans -13 CLA & $<0.01$ & 8.19 \\
\hline Other CLA & $<0.01$ & 12.19 \\
\hline $18: 3$ cis -9, cis -12, cis -15 & 0.26 & 0.07 \\
\hline $20: 0$ & 0.33 & 0.52 \\
\hline Unknown & 2.54 & 2.45 \\
\hline Total CLA & $<0.01$ & 39.98 \\
\hline
\end{tabular}

\footnotetext{
${ }^{1}$ Cows were fed a dietary rumen-protected supplement containing $468 \mathrm{~g}$ fatty acids/d from approximately $10 \mathrm{~d}$ pre-calving to $21 \mathrm{~d}$ postcalving.

${ }^{2} \mathrm{CLA}=$ Conjugated linoleic acid.
}

complete consumption, doses were mixed with equal amounts of steam-flaked corn and dried molasses. Feed was removed, and one-half the supplement was provided at $0600 \mathrm{~h}$; the other half was provided at $1800 \mathrm{~h}$ daily. Feed was returned ( $15 \mathrm{~min})$ to the cows after the entire supplement was consumed. Cows were housed in the Agricultural Research Complex and maintained in tie stalls in an environmentally controlled room with artificial ventilation and 24-h lighting. Cows were fed a TMR formulated to meet or exceed the predicted requirements (NRC, 2001) of energy, protein, minerals, and vitamins using CPM-Dairy (Table 2). Alfalfa hay was the main forage source, and steam-flaked corn was the primary concentrate. The TMR was sampled weekly, composited, and analyzed by wet chemistry methods (Dairy One Cooperative Inc., Ithaca, NY). Cows consumed feed ad libitum with equal portions of fresh feed given twice daily at 0600 and $1800 \mathrm{~h}$; orts were weighed and recorded daily at $0530 \mathrm{~h}$. Water was available at all times.

Cows were milked at 0600 and $1800 \mathrm{~h}$. Yield was recorded daily and averaged by week for statistical analysis; milk samples were obtained from each cow on d 1, 3, 5, 7, 9, 11, 13, 15, 17, 19, and 21 (both milkings). One aliquot from each sampling was stored at $4^{\circ} \mathrm{C}$ with a preservative (bronopol tablet; D\&F Control System, San Ramon, CA), and component content was analyzed at the Arizona DHIA (Tempe, AZ) using AOAC (2000) approved infrared analysis equipment and procedures. A second aliquot was stored at $-20^{\circ} \mathrm{C}$ until analyzed for fatty acid composition. Blood samples were obtained from each cow on the same days that milk was sampled. 
Table 2. Ingredients and chemical composition of diets. ${ }^{1}$

\begin{tabular}{lcc}
\hline Composition & Prepartum & Postpartum \\
\hline Ingredient, \% of DM & & \\
Alfalfa hay & 68.1 & 60.5 \\
Bermuda hay & 3.9 & \\
Whole cottonseed & 3.9 & 5.7 \\
Distillers grain & & 3.0 \\
Fat bran (15\% tallow) & & 5.7 \\
Molasses & 7.7 & 2.8 \\
Citrus pulp & 11.6 & 5.7 \\
Steam-flaked corn & 4.8 & 12.3 \\
Mineral and vitamin mix $^{2,3}$ & & 4.3 \\
Chemical analysis, \% of DM & 18.8 & \\
CP & 42.8 & 17.6 \\
NDF & 26.9 & 27.5 \\
ADF & 1.58 & 1.63 \\
NE &
\end{tabular}

${ }^{1}$ Values represent an average of samples collected and composited throughout the trial. Dry matter averaged 93 and $92 \%$ for the prepartum and postpartum diets, respectively.

${ }^{2}$ The prepartum supplement contained $9.5 \% \mathrm{Ca}, 3.1 \% \mathrm{P}, 3.0 \% \mathrm{Mg}$, $3.0 \% \mathrm{~S}, 1364 \mathrm{mg} / \mathrm{kg}$ of $\mathrm{Zn}, 1223 \mathrm{mg} / \mathrm{kg}$ of $\mathrm{Mn}, 928 \mathrm{mg} / \mathrm{kg}$ of Fe, 452 $\mathrm{mg} / \mathrm{kg}$ of Cu, $49 \mathrm{mg} / \mathrm{kg}$ of Co, $9 \mathrm{mg} / \mathrm{kg}$ Se, $435 \mathrm{IU} / \mathrm{g}$ of vitamin A, 43 $\mathrm{IU} / \mathrm{g}$ of vitamin $\mathrm{D}$, and $21.5 \mathrm{IU} / \mathrm{g}$ of vitamin $\mathrm{E}$.

${ }^{3}$ The postpartum supplement contained $3.25 \% \mathrm{Ca}, 3.5 \% \mathrm{P}, 3.5 \%$ $\mathrm{Mg}, 1.0 \% \mathrm{~S}, 1688 \mathrm{mg} / \mathrm{kg}$ of Zn, $1464 \mathrm{mg} / \mathrm{kg}$ of $\mathrm{Mn}, 1568 \mathrm{mg} / \mathrm{kg}$ of Fe, $428 \mathrm{mg} / \mathrm{kg}$ of $\mathrm{Cu}, 48 \mathrm{mg} / \mathrm{kg}$ of Co, $9 \mathrm{mg} / \mathrm{kg} \mathrm{Se}, 244 \mathrm{IU} / \mathrm{g}$ of vitamin A, $24 \mathrm{IU} / \mathrm{g}$ of vitamin $\mathrm{D}$, and $1 \mathrm{IU} / \mathrm{g}$ of vitamin $\mathrm{E}$.

Samples were kept on ice until centrifuged at $3000 \times g$ for $15 \mathrm{~min}$. Plasma was split into two aliquots that were immediately frozen at $-20^{\circ} \mathrm{C}$ and later analyzed for NEFA and glucose concentrations. Plasma NEFA and glucose concentrations were determined enzymatically using commercially available kits validated for use in our laboratory (NEFA C kit; Wako Chemicals USA, Richmond, VA; Lot \#21P2-1; Autokit Glucose C2; Wako Chemicals USA, Inc., Lot \#TH214). These procedures were scaled down and conducted in 96-well microplates (Rainin Instrument, LLC, Oakland, CA) and read using a microplate photometer (Multiskan Ascent, Thermo Electron Corporation, Vantaa, Finland). The inter- and intra-assay coefficients for the NEFA and glucose assay were $8.11,2.85,3.84$, and $3.21 \%$, respectively.

Body weight was recorded on the day of treatment initiation $(\approx \mathrm{d}-10)$, day of calving, and on 7,14 and 21 DIM. An independent observer blindly evaluated BCS using a 5-point scale on the day of treatment initiation $(\approx \mathrm{d}-10)$ and again on 7 and 21 DIM. Net energy balance was calculated using the following equation: EBAL = net energy intake - (net energy of maintenance + net energy of lactation). Net energy intake was calculated by multiplying the daily DMI by the net energy of the diet plus the net energy value of the supplement (calculated using $2001 \mathrm{NRC}$ energy values for steam-flaked corn, molasses, and calcium soaps of fat). Digestibility and absorbability were assumed to be similar between the two fat supplements. Net energy for maintenance was calculated according to the NRC (2001) using the following equation: net energy of maintenance $=0.08$ $\times \mathrm{BW}^{0.75}$. Net energy for lactation was calculated according to the NRC (2001) by the following equation: net energy for lactation $=((0.0929 \times$ fat $\%)+(0.0547 \times$ $\mathrm{CP} \%)+(0.0395 \times$ lactose $\%)) \times$ milk production. Daily EBAL values were subjected to a third-order polynomial regression analysis to minimize variation, and predicted daily energy values from these equations were used in the statistical analysis as previously described (Lucy et al., 1991). Days to EBAL nadir were identified as the day at which the lowest predicted EBAL value occurred.

\section{Fatty Acid Analysis}

Milk fat from samples collected on d 1, 7, 15, and 21 were extracted according to Hara and Radin (1978), and fatty acid methyl esters were prepared by the transmethylation procedure described by Christie (1982) with modifications (Chouinard et al., 1999a). Fatty acid methyl esters were quantified using a gas chromatograph (Hewlett Packard GC system 6890; Wilmington, $\mathrm{DE}$ ) equipped with a flame ionization detector and a CP-7420 fused silica capillary column $(100 \mathrm{~m} \times 0.25$ $\mathrm{mm}$ i.d. with $0.2 \mu \mathrm{m}$ film thickness; Varian, Walnut Creek, CA). Initial oven temperature $\left(50^{\circ} \mathrm{C}\right)$ was held for $1 \mathrm{~min}$ then ramped at $5^{\circ} \mathrm{C} / \mathrm{min}$ to $160^{\circ} \mathrm{C}$, where it was held for $42 \mathrm{~min}$, and then ramped at $5^{\circ} \mathrm{C} / \mathrm{min}$ to $190^{\circ} \mathrm{C}$ and held for $22 \mathrm{~min}$. Inlet and detector temperatures were maintained at $250^{\circ} \mathrm{C}$, and the split ratio was 100:1. Hydrogen carrier gas flow rate through the column was $1 \mathrm{~mL} / \mathrm{min}$. Hydrogen flow to the detector was $30 \mathrm{~mL} / \mathrm{min}$, airflow was $400 \mathrm{~mL} / \mathrm{min}$, and the nitrogen make-up gas flow was $25 \mathrm{~mL} / \mathrm{min}$. Peaks in the chromatogram were identified and quantified using pure methyl ester standards (GLC60; Nuchek Prep, Elysian, MN; Matreya, Inc., Pleasant Gap, PA, anhydrous milk fat; R.T. Corporation, Laramie, WY), and the CLA profile was identified as previously described (Roach et al., 2002). A butter oil reference standard (anhydrous milk fat; R.T. Corporation, Laramie, WY) was used to determine recoveries and correction factors for individual fatty acids (Baumgard et al., 2000).

\section{Statistical Analysis}

Milk yield, milk components, plasma NEFA and glucose, EBAL, and feed intake were all analyzed with the repeated measures PROC MIXED procedure of SAS (2001) with week of treatment as the repeated effect. The model contained week of treatment, treatment, and week of treatment $\times$ treatment interactions. Fatty acid 
Table 3. Effects of increasing doses of a conjugated linoleic acid (CLA) supplement ${ }^{1}$ on production variables in lactating dairy cows. ${ }^{2}$

\begin{tabular}{|c|c|c|c|c|c|c|}
\hline \multirow[b]{2}{*}{ Parameter } & \multicolumn{4}{|c|}{ CLA supplement, g/d } & \multirow[b]{2}{*}{ SEM } & \multirow[b]{2}{*}{$P$} \\
\hline & 0 & 200 & 400 & 600 & & \\
\hline DMI, kg/d & 17.9 & 16.4 & 18.2 & 16.0 & 2.1 & 0.81 \\
\hline Milk yield, kg/d & 33.4 & 33.7 & 35.5 & 34.3 & 2.5 & 0.94 \\
\hline \multicolumn{7}{|l|}{ Milk fat } \\
\hline$\%$ & $4.57^{\mathrm{a}}$ & $3.97^{\mathrm{a}, \mathrm{b}}$ & $3.32^{\mathrm{b}}$ & $3.10^{\mathrm{b}}$ & 0.30 & 0.02 \\
\hline $\mathrm{g} / \mathrm{d}$ & $1465^{\mathrm{a}}$ & $1288^{\mathrm{a}, \mathrm{b}}$ & $1146^{\mathrm{a}, \mathrm{b}}$ & $1026^{\mathrm{b}}$ & 89 & 0.02 \\
\hline \multicolumn{7}{|l|}{ Milk protein } \\
\hline$\%$ & 4.02 & 3.49 & 3.76 & 3.68 & 0.17 & 0.24 \\
\hline $\begin{array}{l}\text { g/d } \\
\text { Milk lactose }\end{array}$ & 1208 & 1191 & 1234 & 1218 & 102 & 0.99 \\
\hline \multicolumn{7}{|l|}{ Milk lactose } \\
\hline$\%$ & 4.67 & 4.53 & 4.64 & 4.60 & 0.10 & 0.79 \\
\hline $\mathrm{g} / \mathrm{d}$ & 1580 & 1540 & 1644 & 1588 & 126 & 0.95 \\
\hline \multicolumn{7}{|l|}{ Milk SNF } \\
\hline$\%$ & 9.56 & 8.89 & 9.28 & 9.18 & 0.25 & 0.36 \\
\hline $\mathrm{g} / \mathrm{d}$ & 3083 & 2986 & 3194 & 3117 & 235 & 0.93 \\
\hline
\end{tabular}

${ }^{\mathrm{a}, \mathrm{b}}$ Different superscripts within a row indicate a $P$-value $<0.05$.

${ }^{1}$ Represent amount of Ca salts of CLA, actual amounts of dietary CLA were 0, 62, 125, and $187 \mathrm{~g} / \mathrm{d}$, respectively.

${ }^{2}$ Data in this table represents weekly means from the entire postpartum period $(21 \mathrm{~d})$.

profile was analyzed by repeated measures with the PROC MIXED procedure of SAS (2001) with day of treatment as the repeated effect. The model contained day of treatment, treatment, and day of treatment $\times$ treatment interactions. Orthogonal contrasts were used to test for linear, quadratic, and cubic effects of treatment.

\section{RESULTS}

There were no differences in DMI (17.1 kg/d), milk yield $(34.2 \mathrm{~kg} / \mathrm{d})$, protein content (3.74), lactose percentage (4.61), or yields of protein or lactose (Table 3 ). The CLA supplementation decreased overall milk fat content in a dose-responsive manner $(4.57,3.97,3.32$, and $3.10 \%$, respectively; $P<0.02$ ), and milk fat yield showed the same progressive decline $(P<0.02)$. The dose-dependent decrease in milk fat content was evident during wk $1(P=0.15)$ and became highly significant $(P<0.01)$ during wk 2 and $3(4.51,3.79,3.20,2.86 \%$ and 3.86 , $3.14,2.55,2.27 \%$ for wk and dose, respectively; Figure 1). The milk fat yield response pattern was similar with the highest CLA supplement decreasing fat yield by $44 \%$ in wk 3.

Body weight and BCS at calving were similar among all four treatments, and the loss of BW and decrease in BCS during the 21-d trial were also similar across treatments (Table 4). Days to EBAL nadir were decreased $(P=0.03)$ by CLA supplementation $(7.3,5.8$, 4.8 , and $2.6 \mathrm{~d}$ for $0,200,400$, and $600 \mathrm{~g} / \mathrm{d}$ dose, respectively). Although there was a large numerical increase in EBAL in wk 2 and 3 with the 2 highest CLA supplements, overall mean EBAL during the first $21 \mathrm{~d}$ of
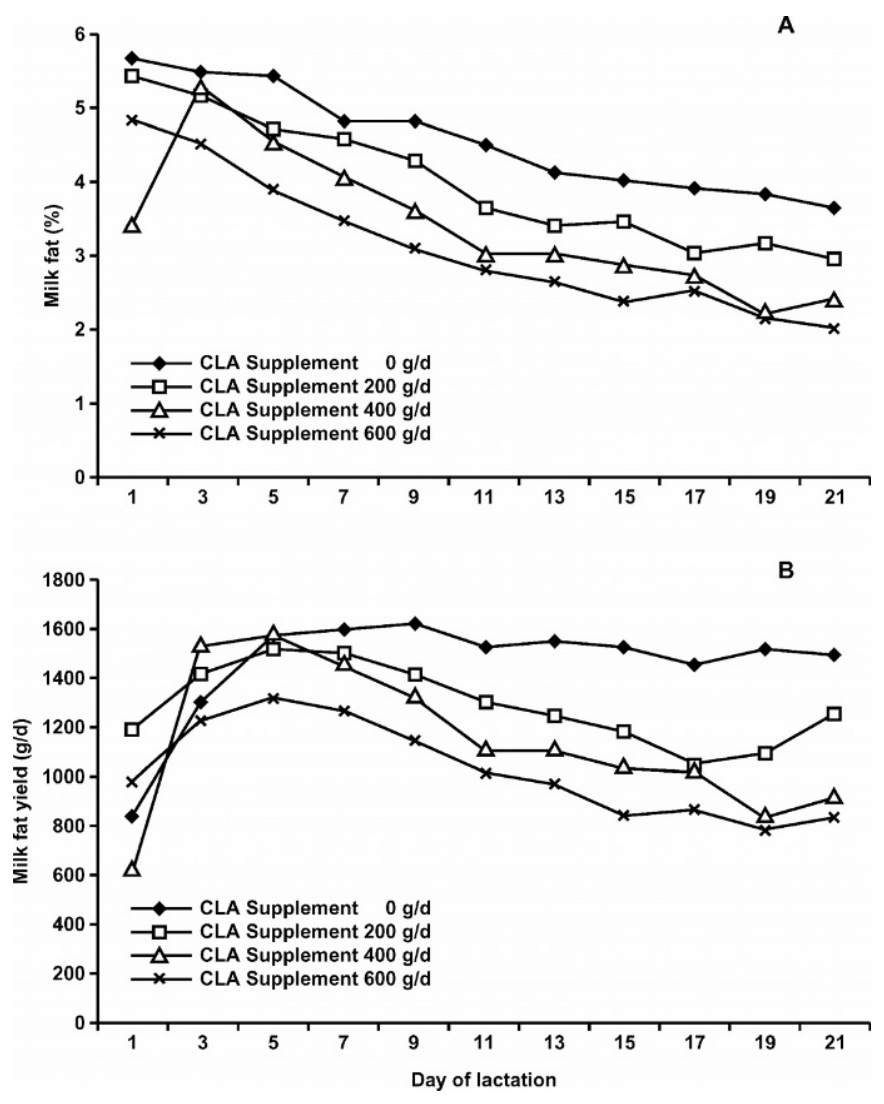

Figure 1. Temporal pattern of milk fat content (A) and milk fat yield (B) from cows fed increasing doses of a rumen-protected conjugated linoleic acid (CLA) supplement during early lactation. Values are means ( $n=4$ or 5 , respectively) for the $0 \mathrm{~g} / \mathrm{d}$ CLA dose and the remaining CLA doses; SEM for milk fat content averaged 0.37 and ranged from 0.36 to $0.41 \%$; SEM for milk fat yield averaged 123 and ranged from 119 to $134 \mathrm{~g} / \mathrm{d}$. 
Table 4. Body weight parameters and metabolic indices associated with the transition period from cows fed increasing amounts of a conjugated linoleic acid (CLA) supplement. ${ }^{1}$

\begin{tabular}{lcccccc}
\hline & \multicolumn{7}{c}{ CLA supplement, g/d } & & \\
\cline { 2 - 5 } Variable & 0 & 200 & 400 & 600 & SEM & $P$ \\
\hline BW at calving, kg & 647 & 685 & 635 & 625 & 29 & 0.49 \\
BW loss, ${ }^{2}$ kg & 64 & 56 & 39 & 57 & 15 & 0.73 \\
BCS at calving & 2.6 & 2.9 & 3.0 & 2.7 & 0.2 & 0.45 \\
BCS loss $^{3}$ & 0.19 & 0.60 & 0.69 & 0.50 & 0.2 & 0.39 \\
EBAL $^{4} \mathrm{Mcal}_{\text {EBAL }}^{5}$ nadir, d & -8.82 & -9.78 & -5.15 & -6.15 & 2.6 & 0.54 \\
NEFA, ${ }^{6} \mu$ eq/L & $7.3^{\mathrm{a}}$ & $5.8^{\mathrm{a}}$ & $4.8^{\mathrm{a}, \mathrm{b}}$ & $2.6^{\mathrm{b}}$ & 1.0 & 0.03 \\
Glucose,6 mg/dL & 362 & 498 & 381 & 465 & 82.3 & 0.61 \\
\hline
\end{tabular}

${ }^{\mathrm{a}, \mathrm{b}}$ Different superscripts within a row indicate a $P$-value $<0.05$.

${ }^{1}$ Represents amount of Ca salts of CLA, actual amounts of dietary CLA were $0,62,125$, and $187 \mathrm{~g} / \mathrm{d}$, respectively.

${ }^{2}$ Calculated as BW change from calving to 21 DIM.

${ }^{3}$ Calculated as the difference in BCS from calving to $21 \mathrm{DIM}$.

${ }^{4} \mathrm{EBAL}=$ net energy balance calculated according to NRC (2001) and represents an average of the 21-d treatment period.

${ }^{5}$ Calculated using a third-order polynomial regression.

${ }^{6}$ Values represent an average of samples obtained during the 21-d treatment period.

lactation was not affected by treatment (Figure 2; Table 4). There were no overall effect of treatment on plasma NEFA or glucose levels (Table 4) and no differences in temporal pattern of these metabolites during the 21-d treatment period (data not shown).

Milk fat concentration of most short- and mediumchain fatty acids were reduced in cows receiving either the 400 or $600 \mathrm{~g} / \mathrm{d}$ CLA supplement (Table 5). This resulted in an overall decrease $(P=0.04)$ in the concentration of de novo $(<\mathrm{C} 16)$ fatty acids and an increase $(P<0.01)$ in preformed $(\geq \mathrm{C} 17)$ fatty acids in milk fat from cows supplemented with increasing amounts of CLA. On a molar basis, the yields of all fatty acids were

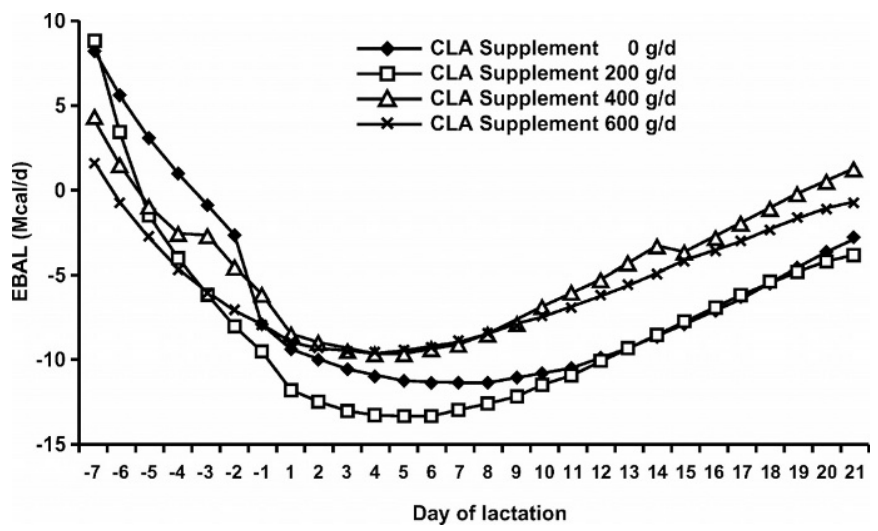

Figure 2. Temporal pattern of calculated net energy balance (EBAL) for cows fed increasing doses of a rumen-protected conjugated linoleic acid (CLA) supplement during early lactation. Values are means ( $n=4$ of 5 , respectively) for the $0 \mathrm{~g} / \mathrm{d}$ CLA dose and the remaining CLA doses; SEM averaged 2.6 and ranged from 2.5 to 2.8 $\mathrm{Mcal} / \mathrm{d}$. reduced with CLA supplementation, but the reduction in de novo synthesized fatty acids was more severe at the 2 larger CLA doses (Figure 3). The reduction in fatty acid yield was more evenly distributed between de novo and preformed fatty acids in the $200-\mathrm{g} / \mathrm{d}$ CLA dose. Dietary CLA supplementation linearly increased $(P<0.01)$ total CLA content in milk fat, with the highest dose increasing CLA levels $>5$-fold (Table 5). The total and specific CLA isomer content ( $\mathrm{mg} / \mathrm{g}$ ) in milk fat was dose dependent and was consistent throughout the trial, which is illustrated by the temporal appearance of trans-10, cis-12 CLA in milk fat (Figure 4). There was no detectable effect of CLA dose on specific $\Delta^{9}$ desaturase pairs or the $\Delta^{9}$-desaturase index (Table 5), and this was temporally independent (data not shown).

\section{DISCUSSION}

Transitioning physiological states, from gestation to lactation, requires extensive metabolic adaptations, and many cows do not (because of health, reproduction, or production problems) complete the transition successfully. It is thought that the magnitude and duration of NEBAL mediates or at least is strongly associated with transition failures (Goff and Horst, 1997; Drackley, 1999). In addition, reduced reproductive performance has been strongly linked not only with the extent but also with the timing of NEBAL nadir (Lucy et al., 1992; Beam and Butler, 1999). To capture most of the metabolic changes and large fluctuations in production variables, we initiated CLA feeding $10 \mathrm{~d}$ prior to anticipated parturition and continued until 21 DIM.

Abomasal infusion (Loor and Herbein, 1998; Chouinard et al., 1999b; Kraft et al., 2000) and dietary RP- 
Table 5. Fatty acid composition of milk fat from cows fed increasing amounts of a conjugated linoleic acid (CLA) supplement. ${ }^{1}$

\begin{tabular}{|c|c|c|c|c|c|c|}
\hline \multirow[b]{2}{*}{ Variable } & \multicolumn{4}{|c|}{ CLA supplement, g/d } & \multirow[b]{2}{*}{ SEM } & \multirow[b]{2}{*}{$P$} \\
\hline & 0 & 200 & 400 & 600 & & \\
\hline Fatty acid & \multicolumn{4}{|c|}{$\longrightarrow\left(\mathrm{mg} / \mathrm{g}\right.$ of fatty acids $\left.{ }^{2}\right)$} & & \\
\hline 4:0 & 80.8 & 101.5 & 78.3 & 62.2 & 11.7 & 0.14 \\
\hline $6: 0$ & $19.4^{\mathrm{a}}$ & $16.4^{\mathrm{a}, \mathrm{b}}$ & $13.7^{\mathrm{b}}$ & $13.6^{\mathrm{b}}$ & 1.2 & 0.01 \\
\hline 8:0 & $6.9^{\mathrm{a}}$ & $5.1^{\mathrm{b}}$ & $4.3^{\mathrm{b}}$ & $4.5^{\mathrm{b}}$ & 0.5 & $<0.01$ \\
\hline $10: 0$ & $11.8^{\mathrm{a}}$ & $8.3^{\mathrm{a}, \mathrm{b}}$ & $7.3^{\mathrm{b}}$ & $7.9^{\mathrm{b}}$ & 0.9 & 0.02 \\
\hline $12: 0$ & $13.6^{\mathrm{a}}$ & $9.9^{\mathrm{a}, \mathrm{b}}$ & $9.3^{\mathrm{b}}$ & $9.8^{\mathrm{a}, \mathrm{b}}$ & 1.0 & 0.04 \\
\hline $14: 0$ & $58.4^{\mathrm{a}}$ & $42.8^{\mathrm{b}}$ & $43.2^{\mathrm{a}, \mathrm{b}}$ & $43.3^{\mathrm{b}}$ & 3.9 & 0.03 \\
\hline $14: 1$ cis -9 & $3.7^{\mathrm{a}}$ & $2.5^{\mathrm{a}, \mathrm{b}}$ & $2.1^{\mathrm{a}, \mathrm{b}}$ & $2.0^{\mathrm{b}}$ & 0.4 & 0.04 \\
\hline $15: 0$ & 5.7 & 4.9 & 5.4 & 5.4 & 0.3 & 0.38 \\
\hline $16: 0$ & 283.3 & 253.8 & 265.2 & 253.3 & 10.5 & 0.21 \\
\hline $16: 1$ cis -9 & 12.0 & 12.6 & 11.0 & 11.5 & 1.5 & 0.89 \\
\hline $17: 0$ & 6.7 & 7.0 & 7.2 & 7.3 & 0.2 & 0.17 \\
\hline 18:0 & $133.0^{\mathrm{a}}$ & $136.1^{\mathrm{a}}$ & $156.3^{\mathrm{a}, \mathrm{b}}$ & $165.8^{\mathrm{b}}$ & 7.7 & 0.02 \\
\hline $18: 1$ trans $-6-8$ & $4.1^{\mathrm{a}}$ & $4.4^{\mathrm{a}, \mathrm{b}}$ & $4.6^{\mathrm{a}, \mathrm{b}}$ & $5.2^{\mathrm{b}}$ & 0.3 & 0.05 \\
\hline $18: 1$ trans -9 & 3.4 & 3.5 & 3.7 & 3.9 & 0.2 & 0.27 \\
\hline $18: 1$ trans -10 & 6.0 & 6.3 & 6.8 & 7.0 & 0.4 & 0.28 \\
\hline $18: 1$ trans -11 & 13.1 & 11.1 & 11.1 & 10.4 & 0.8 & 0.17 \\
\hline 18:1 trans -12 & 4.9 & 4.5 & 5.1 & 5.3 & 0.3 & 0.20 \\
\hline $18: 1$ cis -9 & 238.2 & 266.0 & 253.1 & 259.5 & 13.8 & 0.56 \\
\hline $18: 2$ cis -9, cis -12 & 36.6 & 40.5 & 39.6 & 40.2 & 1.4 & 0.25 \\
\hline 18:2 trans -8, cis-10 CLA & $<0.1^{\mathrm{a}}$ & $0.4^{\mathrm{a}, \mathrm{b}}$ & $0.9^{\mathrm{b}}$ & $1.6^{\mathrm{c}}$ & 0.1 & $<0.01$ \\
\hline 18:2 cis -9, trans -11 CLA & 3.4 & 3.1 & 3.5 & 4.2 & 0.3 & 0.09 \\
\hline 18:2 trans -10, cis-12 CLA & $<0.1^{\mathrm{a}}$ & $0.8^{\mathrm{a}, \mathrm{b}}$ & $1.6^{\mathrm{b}, \mathrm{c}}$ & $2.5^{\mathrm{c}}$ & 0.3 & $<0.01$ \\
\hline 18:2 cis-11, trans-13 CLA & $<0.1^{\mathrm{a}}$ & $0.8^{\mathrm{a}}$ & $1.8^{\mathrm{b}}$ & $3.0^{\mathrm{c}}$ & 0.2 & $<0.01$ \\
\hline Other CLA & $1.5^{\mathrm{a}}$ & $5.6^{\mathrm{a}, \mathrm{b}}$ & $9.3^{\mathrm{b}}$ & $15.7^{\mathrm{c}}$ & 1.5 & $<0.01$ \\
\hline $18: 3$ cis -9, cis -12, cis -15 & $1.1^{\mathrm{a}, \mathrm{b}}$ & $1.1^{\mathrm{a}}$ & $1.3^{\mathrm{a}, \mathrm{b}}$ & $1.3^{\mathrm{b}}$ & 0.1 & 0.03 \\
\hline $20: 0$ & 3.8 & 4.1 & 4.1 & 4.2 & 0.4 & 0.86 \\
\hline Unknown & 48.6 & 47.8 & 52.0 & 49.6 & 4.5 & 0.92 \\
\hline Total CLA & $5.1^{\mathrm{a}}$ & $10.8^{\mathrm{a}, \mathrm{b}}$ & $17.0^{\mathrm{b}}$ & $26.9^{\mathrm{c}}$ & 2.2 & $<0.01$ \\
\hline Total $18: 1$ trans & 31.5 & 29.7 & 31.3 & 31.8 & 1.7 & 0.81 \\
\hline \multicolumn{7}{|l|}{$\Delta^{9}$ Ratios } \\
\hline $14: 1 / 14: 0$ & 0.06 & 0.06 & 0.05 & 0.05 & $<0.01$ & 0.64 \\
\hline $16: 1 / 16: 0$ & 0.04 & 0.05 & 0.04 & 0.05 & $<0.01$ & 0.67 \\
\hline $18: 1 / 18: 0$ & 1.91 & 1.99 & 1.65 & 1.63 & 0.17 & 0.34 \\
\hline c9, $t 11$ CLA/18:1 t11 & $0.28^{\mathrm{a}}$ & $0.29^{\mathrm{a}}$ & $0.32^{\mathrm{a}}$ & $0.41^{\mathrm{b}}$ & 0.01 & $<0.01$ \\
\hline$\Delta^{9}$ Desaturase index ${ }^{3}$ & 35.0 & 39.0 & 37.0 & 37.0 & 2.0 & 0.42 \\
\hline \multicolumn{7}{|l|}{ Fatty acid origin } \\
\hline De novo 4 & $200.3^{\mathrm{a}}$ & $190.9^{a, b}$ & $162.5^{\mathrm{a}, \mathrm{b}}$ & $148.5^{\mathrm{b}}$ & 13.3 & 0.04 \\
\hline $16: 0 \& 16: 1$ & 295.3 & 266.5 & 276.3 & 264.8 & 11.0 & 0.24 \\
\hline Preformed $^{5}$ & $455.8^{\mathrm{a}}$ & $495.1^{\mathrm{a}, \mathrm{b}}$ & $509.3^{\mathrm{b}}$ & $537.1^{\mathrm{b}}$ & 11.9 & $<0.01$ \\
\hline
\end{tabular}

a,b,c Different superscripts within a row indicate a $P$-value $<0.05$.

${ }^{1}$ Represents amount of Ca salts of CLA, actual amounts of dietary CLA were $0,62,125$, and $187 \mathrm{~g} / \mathrm{d}$, respectively.

${ }^{2}$ Values represent an average of samples obtained during the 21-d treatment period.

${ }^{3} \Delta^{9}$ Desaturase index calculated by $100 \times\left(\left(\mathrm{C}_{14: 1}+\mathrm{C}_{16: 1}+\mathrm{C}_{18: 1}\right) /\left(\mathrm{C}_{14: 1}+\mathrm{C}_{16: 1}+\mathrm{C}_{18: 1}+\mathrm{C}_{14: 0}+\mathrm{C}_{16: 0}+\mathrm{C}_{18: 0}\right)\right)$

${ }^{4}<\mathrm{C} 16: 0$.

${ }^{5}>\mathrm{C} 16: 1$.

CLA supplements (Giesy et al., 2002; Perfield et al., 2002) decrease milk fat synthesis during established lactation, but similar amounts of RP-CLA supplements had little or no effect on decreasing milk fat immediately following parturition (Giesy et al., 1999; Selberg et al., 2002; Bernal-Santos et al., 2003). Our hypothesis was that the early lactating mammary gland is less sensitive to CLA. Reasons for the insensitivity are not clear, but it is possible that milk fat synthesizing genes are resistant (for evolutionary purposes) to manipulation at this time. Alternatively, the binding and cellular incorporation of NEFA (extensively mobilized from fat reserves, which results in a greater proportion of longchain fatty acids in early lactation milk fat) competitively prevent adequate epithelial CLA uptake. Therefore, because of the aforementioned possibilities or an unknown mechanism, we theorized that a larger CLA dose is required to achieve milk fat reductions similar to 
Day 1

CLA Supplement (g/d)

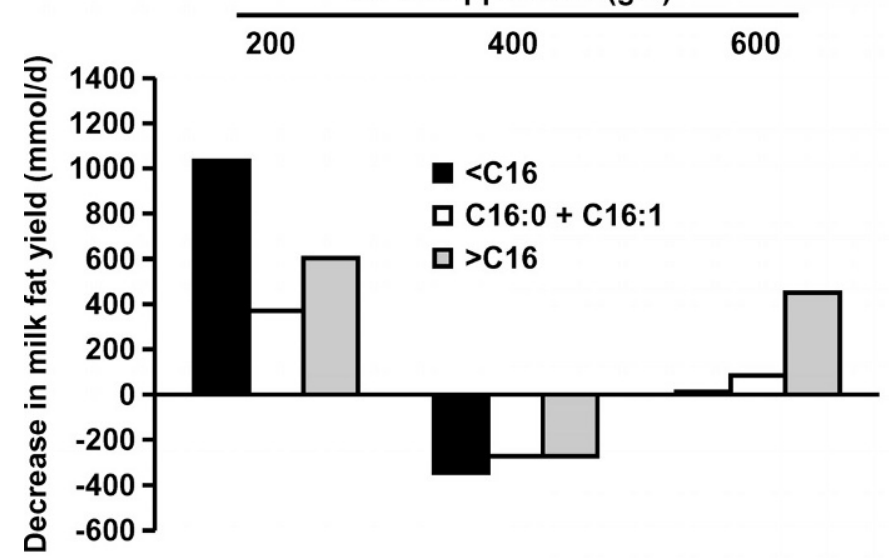

Day 15 CLA Supplement (g/d)

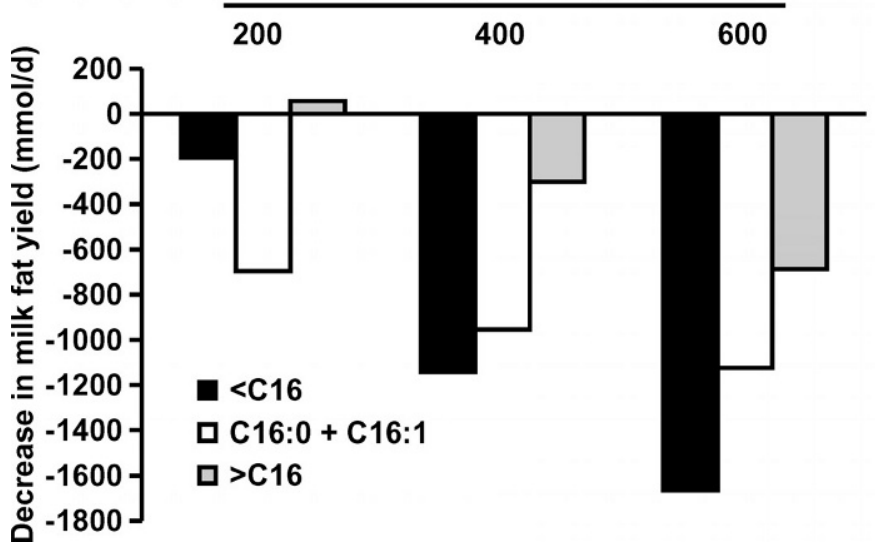

Day 7

CLA Supplement (g/d)

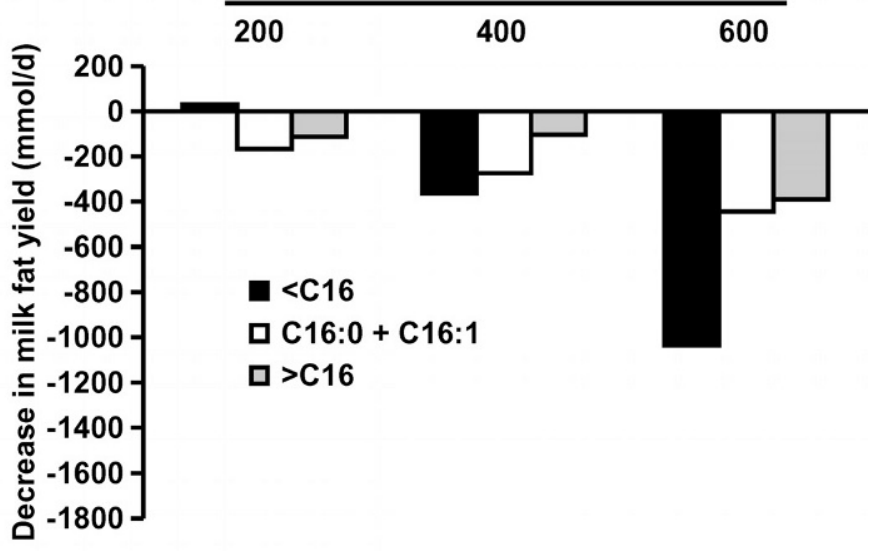

Day 21

CLA Supplement (g/d)

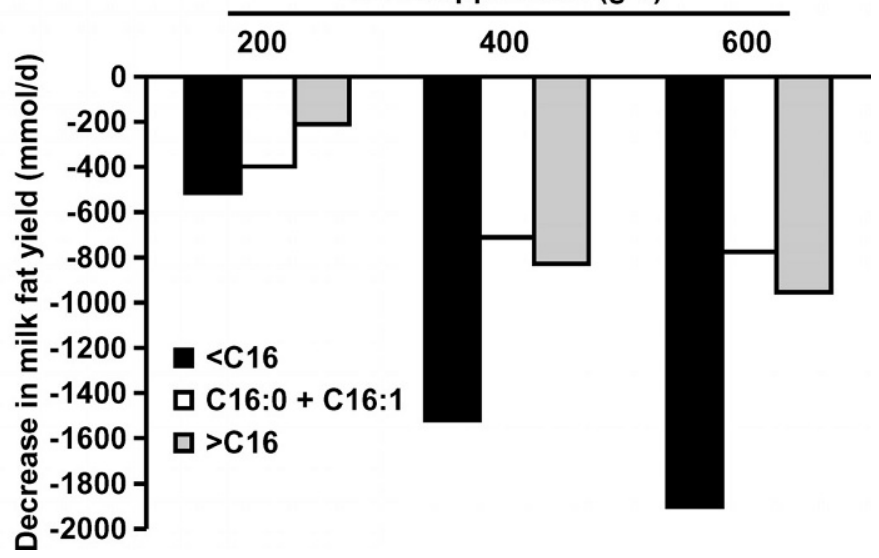

Figure 3. Reduction in milk fatty acids from cows compared with control ( 0 g/d CLA) on 1, 7, 15, and 21 DIM following supplementation of increasing doses of rumen-protected conjugated linoleic acid (CLA). The proportional reduction in fatty acids (mmol/d) is partitioned by origin: de novo $(<\mathrm{C} 16: 0)$, de novo and preformed (C16:0 and C16:1), and preformed $(\geq \mathrm{C} 17: 0)$.

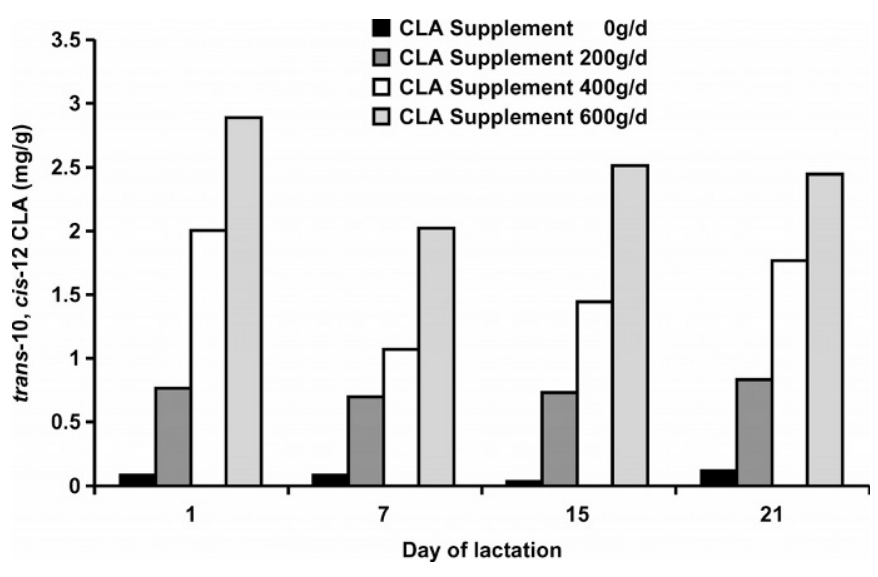

Figure 4. Temporal appearance of trans-10, cis-12 CLA (mg/g) in milk fat from cows fed increasing amounts of a rumen-protected conjugated linoleic acid (CLA) supplement during early lactation. those observed in established lactation. In the current study, we demonstrated that RP-CLA supplements can reduce milk fat content and yield; effects were apparent at $\mathrm{d} 1$ of lactation, significantly different by 5 DIM, and became more pronounced as DIM increased (Table 3; Figure 1). During the first $21 \mathrm{~d}$ of lactation, RP-CLA supplements decreased milk fat in a curvilinear manner with the 2 highest doses reducing overall milk fat content by 27 and $32 \%$ and reducing milk fat yield by 22 and $33 \%$, respectively. By the end of the trial (21 DIM), the highest CLA dose decreased milk fat (content and yield) by approximately 50\% (Figure 1).

The yield and content of milk components other than milk fat were unaltered in this trial, which is similar to results reported in other CLA studies (Chouinard et al., 1999a, 1999b; Baumgard et al., 2000, 2001; Giesy et al., 2002; Perfield et al., 2002; Peterson et al., 2002). However, we have hypothesized that reducing milk fat 
synthesis in early lactation, a time when nutrient availability may limit production, may allow for energy partitioning to support increased protein and milk synthesis (Bauman et al., 2001; Baumgard et al., 2002b) as has been observed from cows on pasture in established lactation (Medeiros et al., 2000; Mackle et al., 2003). Nevertheless, no effects on the yield of milk or milk protein were observed in the current study. A lack of an effect may in part be due to our study containing a small number of animals, in addition to being conducted during the rapid incline phase of milk yield, and it is possible that an effect would not be detected until milk production plateaus.

In agreement with previous CLA trials (Loor and Herbein, 1998, 2003; Chouinard et al., 1999a,b; Baumgard et al., 2000, 2002a; Perfield et al., 2002; Mackle et al., 2003), the percentage of most short- and mediumchain fatty acids decreased, and the content of a few long-chain fatty acids (primarily stearate) increased (Table 5). When evaluated on a molar basis, yield of all fatty acids decreased, but the reduction in de novo $(\leq \mathrm{C} 16: 1)$ derived fatty acids (especially as lactation progressed) on $d 21$ explained $65 \%$ of the reduction in the $200 \mathrm{~g} / \mathrm{d}$ CLA supplement, $77 \%$ of the reduction in the $400 \mathrm{~g} / \mathrm{d}$ CLA supplement and $84 \%$ of the reduction in the highest CLA dose. We have shown that trans-10, cis-12 CLA decreases the expression of genes involved with de novo fatty acid synthesis (acetyl CoA carboxylase and fatty acid synthetase) in established lactation (Baumgard et al., 2002a), and it appears that a CLA mixture, if provided in a high enough dose, may have the same effect in early lactation. Although not to the same extent, preformed fatty acid uptake was decreased by all CLA doses (Figure 3), presumably because of reduced lipoprotein lipase expression, as we have shown that mammary lipoprotein lipase mRNA was decreased by trans-10, cis-12 CLA in established lactation (Baumgard et al., 2002a).

A lack of an effect on specific $\Delta^{9}$-desaturase pairs and the $\Delta^{9}$-desaturase index (Table 5) was surprising, as most CLA infusion experiments demonstrating extensive ( $>25 \%)$ MFD report a decrease in the $\Delta^{9}$-desaturase system (Chouinard et al., 1999a, 1999b; Baumgard et al., 2000, 2002a; Peterson et al., 2002; Loor and Herbein, 2003). In addition, Perfield et al. (2002) indicated that RP-CLA also decreases the $\Delta^{9}$-desaturase system. However, a lack of CLA effect on the $\Delta^{9}$-desaturase system in the present study is consistent with results indicating that a reduction in desaturation capability is not necessary for mild MFD (10 to 25\%; Baumgard et al., 2001; Peterson et al., 2002). The $\Delta^{9}$-desaturase enzyme plays a critical role in regulating cellular membrane and milk fat triglyceride fluidity by introducing a cis-9 double bond (thus lowering the melting point) in fatty acids (Parodi, 1982). This desaturase system is inhibited by a CLA mixture (Chouinard et al., 1999a, 1999b) and specifically trans-10, cis-12 CLA (Park et al., 2000; Baumgard et al., 2000, 2002a). However, the quantitative contribution of the $\Delta^{9}$-desaturase enzyme would likely not be as prominent immediately postpartum, as a larger proportion of milk unsaturated fatty acids containing a cis-9 double bond are derived from the circulating fatty acid pool. Therefore, a reduction in the $\Delta^{9}$-desaturase system may not be required for extensive MFD in early lactation. Furthermore, we hypothesized that adipose derived fatty acids, which are markedly increased following parturition, saturate the mammary epithiel cell fatty acid transport system and, thus, interfere with and reduce CLA uptake. However, even though reductions in milk fat content and yield became more pronounced as lactation progressed (Figure 1), total milk fat CLA (data not shown) and specific trans-10, cis-12 CLA content (Figure 4) were consistent throughout the treatment period.

Although milk fat synthesis was markedly decreased in the early stages of lactation (Table 3; Figure 1) and there was a numerical improvement $(\geq 4 \mathrm{Mcal} / \mathrm{d})$ in EBAL during the 2nd and 3rd wk, overall net EBAL was unaffected by CLA dose (Table 4; Figure 2). This result was surprising as milk yield, DMI, and other milk components (Table 3) were unaltered by treatment, but this is probably explained by the small number of animals receiving each dose $(n=4$ or 5$)$ and the large variation typically observed in calculated EBAL (Vicini et al., 2002). We would expect significant improvements in EBAL in a study utilizing a larger number of animals in which EBAL was the primary measurement in question.

Although overall EBAL was not statistically different, CLA did decrease $(P=0.03)$ days to EBAL nadir compared with controls by 3.2 and $4.7 \mathrm{~d}$ for the 2 highest doses, respectively (Table 4). This is relevant, as recovery of EBAL from its nadir in early lactation provides an important signal for initiating ovarian activity (Lucy et al., 1992; Beam and Butler, 1999) and days to nadir is highly correlated with days to first ovulation (Butler, 2001). This evidence suggests that RP-CLA supplements during the transition period may positively impact reproduction.

The lack of an effect of CLA on plasma NEFA concentrations was unexpected (Table 4), as we hypothesized that utilizing CLA to cause extensive MFD would reduce the extent of adipose tissue mobilization. The temporal pattern (which is consistent with the literature; data not shown) and overall NEFA levels provide no evidence for a reduction in fat mobilization, which is consistent with previous CLA research (Baumgard et al., 2000; Bernal-Santos, 2003). It may be that the sig- 
nal to mobilize adipose tissue in early lactation is independent of both EBAL and the mammary gland's fatty acid requirements, but instead more reflects the oxidation needs of extra-mammary tissues in a homeorhetic effort to spare glucose (required for mammary lactose synthesis). The temporal pattern (data not shown) and overall plasma glucose levels were comparable with cows in this stage of lactation and were not altered by CLA dose (Table 4).

Using the milk fat yield of trans-10, cis-12 CLA, we calculated an overall transfer efficiency (from the supplement to milk fat) of $6.7 \%$, which was dose and DIM independent $(P>0.35$; data not reported). This is in contrast to the $22 \%$ transfer efficiency we observed during abomasal infusions of pure trans-10, cis-12 CLA (Baumgard et al., 2000, 2001, 2002a; Peterson et al., 2002), but higher than reported in a previous RP-CLA trial (3.4\%; Perfield et al., 2002). Nonetheless, it is clear a majority of the CLA Ca salts were not inert and, thus, metabolized in the rumen.

\section{CONCLUSION}

The present study demonstrates that dietary CLA supplements cause a reduction in milk fat at the onset of lactation, but the CLA dose required is much greater than is necessary to cause a similar reduction in milk fat synthesis during established lactation. Additional studies are required to determine whether RP-CLA can be utilized as a management tool to manipulate EBAL and improve production, enhance animal well being, and increase reproductive parameters during the transition period.

\section{ACKNOWLEDGMENTS}

The authors express their appreciation to Dan Luchini and Bioproducts Inc. for the donation of Ca salts of CLA and EnerGII. The assistance of Bob Collier, Jane Kay, Debby Dwyer, Mike Dwyer, and Steve and Nancy Faber is also greatly appreciated.

\section{REFERENCES}

Association of Official Analytical Chemists, International. 2000. Official Methods of Analysis. 17th Ed. AOAC, Arlington, VA.

Bauman, D. E., B. A. Corl, L. H. Baumgard, and J. M. Griinari. 2001. Conjugated linoleic acid (CLA) and the dairy cow. Pages 221-250 in Recent Advances in Animal Nutrition. P. C. Garnsworthy and J. Wiseman, ed. Nottingham University Press, Nottingham, UK.

Baumgard, L. H., B. A. Corl, D. A. Dwyer, A. Saebo, and D. E. Bauman. 2000. Identification of the conjugated linoleic acid isomer that inhibits milk fat synthesis. Am. J. Physiol. 278:R179-R184.

Baumgard, L. H., J. K. Sangster, and D. E. Bauman. 2001. Milk fat synthesis in dairy cows is progressively reduced by increasing supplemental amounts of trans-10, cis-12 conjugated linoleic acid (CLA). J. Nutr. 131:1764-1769.
Baumgard, L. H., E. Matitashvili, B. A. Corl, D. A. Dwyer, and D. E. Bauman. 2002a.trans-10,cis-12 conjugated linoleic acid decreases lipogenic rates and expression of genes involved in milk lipid synthesis in dairy cows. J. Dairy Sci. 85:2155-2163.

Baumgard, L. H., C. E. Moore, and D. E. Bauman. 2002b. Potential application of conjugated linoleic acids in nutrient partitioning. Pages 127-141 in Proc. Southwest Nutr. Conf. [Online]. Available: http://animal.cals.arizona.edu/swnmc/2002/index.php. Accessed Dec. 1, 2002.

Beam, S. W., and W. R Butler. 1999. Effects of energy balance on follicular development and first ovulation in postpartum dairy cows. J. Reprod. Fertility 54:411-424.

Bernal-Santos, G., J. W. Perfield, II, D. M. Barbano, D. E. Bauman, and T. R. Overton. 2003. Production responses of dairy cows to dietary supplementation with conjugated linoleic acid (CLA) during the transition period and early lactation. J. Dairy Sci. 86:3218-3228.

Butler, W. R. 2001. Nutritional effects on resumption of ovarian cyclicity and conception rate in postpartum dairy cows. Anim. Sci. Occas. Publ. 26:133-145.

Christie, W. W. 1982. A simple procedure for rapid transmethylation of glycerolipids and cholesteryl esters. J. Lipid Res. 23:1072-1075.

Chouinard, P. Y., L. Corneau, D. M. Barbano, L. E. Metzger, and D. E. Bauman. 1999a. Conjugated linoleic acids alter milk fatty acid composition and inhibit milk fat secretion in dairy cows. J. Nutr. 129:1579-1584.

Chouinard, P. Y., L. Corneau, A. Saebo, and D. E. Bauman. 1999b. Milk yield and composition during abomasal infusion of conjugated linoleic acids in dairy cows. J. Dairy Sci. 82:2737-2745.

Drackley, J. K. 1999. Biology of dairy cows during the transition period: The final frontier? J. Dairy Sci. 82:2259-2273.

Giesy, J. G., S. Viswanadha, T. W. Hanson, L. R. Falen, M. A. McGuire, C. H. Skarie, and A. Vinci. 1999. Effects of calcium salts of conjugated linoleic acid (CLA) on estimated energy balance in Holstein cows early in lactation. J. Dairy Sci. 82(Suppl. 1):74. (Abstr.)

Giesy, J. G., M. A. McGuire, B. Shafii, and T. W. Hanson. 2002. Effect of dose of calcium salts of conjugated linoleic acid (CLA) on percentage and fatty acid content of milk fat in midlactation Holstein cows. J. Dairy Sci. 85:2023-2029.

Goff, J. P., and R. L. Horst. 1997. Physiological changes at parturition and their relationship to metabolic disorders. J. Dairy Sci. 80:1260-1268.

Grummer, R. R., P. C. Hoffman, M. L. Luck, and S. J. Bertics. 1995. Effect of prepartum and postpartum dietary energy on growth and lactation of primiparous cows. J. Dairy Sci. 78:172-180.

Hara, A., and N. S. Radin. 1978. Lipid extraction of tissues with a low-toxicity solvent. Anal. Biochem. 90:420-426.

Harrell, R. J., O. Phillips, D. L. Jerome, R. D. Boyd, D. A. Dwyer, and D. E. Bauman. 2000. Effects of conjugated linoleic acid on milk composition and baby pig growth in lactating sows. J. Anim. Sci. 78(Suppl. 1):137-138. (Abstr.)

Kraft, J., P. Lebzien, P. Mockel, and G. Jahreis. 2000. Duodenal infusion of conjugated linoleic acid mixture influences milk fat synthesis and milk CLA content in dairy cows. Pages 143-147 in Milk Composition. R. E. Agnew, A. K. Agnew, and A. M. Fearon, ed. Occasional Publication No. 25, Br. Soc. Anim. Sci. Edinburgh, UK.

Loor, J. J., and J. H. Herbein. 1998. Exogenous conjugated linoleic acid isomers reduce bovine milk fat concentration and yield by inhibiting de novo fatty acids synthesis. J. Nutr. 128:2411-2419.

Loor, J. J., and J. H. Herbein. 2003. Reduced fatty acid synthesis and desaturation due to exogenous trans10, cis12-CLA in cows fed oleic or linoleic oil. J. Dairy Sci. 86:1354-1369.

Lucy, M. C., C. R. Staples, F. M. Michel, and W. W. Thatcher. 1991. Energy balance and size and number of ovarian follicles detected by ultrasonography in early postpartum dairy cows. J. Dairy Sci. 74:473-482.

Lucy, M. C., C. R. Staples, W. W. Thatcher, P. S. Erickson, R. M. Cleale, J. L. Firkins, J. H. Clark, M. R. Murphy, and B. O. Brodie. 1992. Influence of diet composition, dry matter intake, milk pro- 
duction and energy balance on time of postpartum ovulation and fertility in dairy cows. Anim. Prod. 54:323-331.

Mackle, T. R., J. K. Kay, M. J. Auldist, A. K. H. McGibbon, B. A. Philpott, L. H. Baumgard, and D. E. Bauman. 2003. Effects of abomasal infusion of conjugated linoleic acid on milk fat concentration and yield from pasture-fed dairy cows. J. Dairy Sci. 86:644-652.

Masters, N., M. A. McGuire, K. A. Beerman, N. Dasgupta, and M. K. McGuire. 2002. Maternal supplementation with CLA decreases milk fat in humans. Lipids 37:133-138.

Medeiros, S. R., D. E. Oliveira, L. J. M. Aroeira, M. A. McGuire, D. E. Bauman, and D. P. D. Lanna. 2000. The effect of long-term supplementation of conjugated linoleic acid (CLA) to dairy cows grazing tropical pasture. J. Dairy Sci. 83(Suppl. 1):169. (Abstr.)

National Research Council. 2001. Nutrient Requirements of Dairy Cattle. 7th rev. ed. Natl. Acad. Press, Washington, DC.

Park. Y, J. M. Storkson, J. M. Ntambi, M. E. Cook, C. J. Sih, and M. W. Pariza. 2000. Inhibition of hepatic stearoyl-CoA desaturase activity by trans-10, cis-12 conjugated linoleic acid and its derivatives Biochim. Biophys. Acta 1486:285-292.

Parodi, P. W. 1982. Positional distribution of fatty acids in the triglyceride classes of milk fat. J. Dairy Res. 49:73-80.
Perfield, II, J. W., G. Bernal-Santos, T. R. Overton, and D. E. Bauman. 2002. Effects of dietary supplementation of rumen-protected conjugated linoleic acid in dairy cows during established lactation. J. Dairy Sci. 85:2609-2617.

Peterson, D. G., L. H. Baumgard, and D. E. Bauman. 2002. Short communication: Milk fat response to low doses of trans-10, cis12 conjugated linoleic acid (CLA). J. Dairy Sci. 85:1764-1766.

Poulos, S. P., M. J. Azain, and G. J. Hausman. 2000. In utero dietary conjugated linoleic acid (CLA) alters body composition and growth rate in newborn pigs. J. Dairy Sci. 83(Suppl. 1):137. (Abstr.)

Roach, J. A. G., M. M. Mossoba, M. P. Yurawecz, and J. K. G. Kramer. 2002. Chromatographic separation and identification of conjugated linoleic acid isomers. Anal. Chimica Acta 465:207-226.

SAS. 2001. SAS/STAT Users Guide. Release 8.0. SAS Inst., Inc., Cary, NC.

Schingoethe, D. J., and D. P. Casper. 1991. Total lactational response to added fat during early lactation. J. Dairy Sci. 74:2617-2622.

Selberg, K. T., C. R. Staples, and L. Badinga. 2002. Production and metabolic responses to dietary conjugated linoleic acid (CLA) and trans-octadecenoic acid isomers in periparturient Holstein cows. J. Dairy Sci. 85(Suppl. 1):19. (Abstr.)

Vicini, J. L., B. A. Crooker, and M. A. McGuire. 2002. Energy balance in early lactation dairy cows. Pages $1-8$ in Proc. Cal. Anim. Nutr. Conf. 